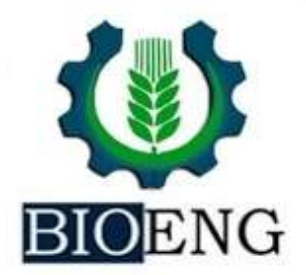

\title{
BROMATOLOGICAL AND SENSORIAL EVALUATION OF PERESKIA ACULEATA USE IN PASTA DOUGH ${ }^{\dagger}$
}

${ }^{1}$ UNESP - Univ Estadual Paulista, Faculdade de Ciências e Engenharia, Campus Tupã, Tupã, SP, Brasil

${ }^{2}$ FATEC - Faculdade de Tecnologia de Presidente Prudente, Presidente Prudente, SP, Brasil

${ }^{3}$ FAI - Faculdades Adamantinenses Integradas, Adamantina, SP, Brasil

Article history: Received 06 July 2016; Received in revised form 29 July 2016; Accepted 01 August 2016; Available online 29 September 2016.

\begin{abstract}
The aim of this study was to analyze and study the nutritional quality of vegetables orapro-nobis (Pereskia aculeata). It is a shrub, where its leaves can be used to supplement the power of low-income people and animals, as well as to serve as decorations and protective fences. The non-traditional vegetables can be an alternative to combat malnutrition. As they are good sources of nutrients, easily grown and have a low market value. In this work have been formulated masses with the plant in question and evaluated how much to its acceptability. The study showed that the ora-pro-nobis presents considerable crude protein and mineral matter. The sensory test showed a great acceptability of the formulated mass with the plant.
\end{abstract}

Keywords: Green vegetables, Food, Descriptive analysis

\section{AVALIAÇÃO BROMATOLÓGICA E SENSORIAL DA UTILIZAÇÃO DE PERESKIA ACULEATA EM MASSA DE MACARRÃO}

\section{RESUMO}

O objetivo do presente trabalho tem como princípio analisar e estudar a qualidade nutricional da hortaliça ora-pro-nóbis (Pereskia aculeata). Este se trata de um arbusto, onde suas folhas podem ser utilizadas para complementar a alimentação da população e dos animais, além de servir como ornamento e cercas de proteção. As hortaliças não tradicionais podem ser uma alternativa para combater a desnutrição de famílias com baixa renda. Já que são boas fontes de nutrientes, fáceis de serem cultivadas e apresentam baixo valor de mercado. Neste trabalho foram formuladas massas com a planta em questão e avaliadas quanto à sua aceitabilidade. $\mathrm{O}$ estudo mostrou que a ora-pró-nobis apresenta consideráveis teores de proteína bruta e matéria mineral. $\mathrm{O}$ teste sensorial mostrou uma ótima aceitabilidade da massa formulada com a planta.

Palavras-chave: Hortaliça, Alimentos, Análise descritiva

\footnotetext{
${ }^{\dagger}$ Parte deste trabalho foi apresentada no XLV Congresso Brasileiro de Engenharia Agrícola.

* camila@tupa.unesp.br
} 


\section{INTRODUCTION}

With population growth and the advancement of technologies in the Medicine, the use and commercialization of plants has increased gradually in recent years. The search for greater diversity and quantity of plants that can be used in the cared health are issues discitis's in several studies (EMBRAPA, 2012).

It is well known, the great interest in developing and expanding research related to therapeutic properties found in certain plants (AZEVEDO and KRUEL, 2012). In Brazil, is to occur due to the lack of public resources allocated to health and the high cost of marketing of these medicines and their collateral effects (MAIOLIAZEVEDO; FONSECA-KRUEL, 2007).

For presenting low market value unconventional vegetables can be an alternative for low-income populations. However, the lack of information or even the lack of interest on the part of the population causes consumption to be taken from daily meals of the population (ROCK, et al., 2008).

The ora-pro-nobis (Pereskia aculeata Miller) is a plant that belongs to cactaceous family and that can be considered as a nutritional supplement for underprivileged families as it is in their

\section{MATERIALS AND METHODS}

The chemical analysis, macro and micronutrients were performed in the laboratory of plant tissue and dough preparation was carried out in the food technology laboratory at the University of West Paulista (UNOESTE ) in the period from September to October 2012.

The leaves were washed in running water with mild detergent. Then the leaves were submerged in a solution of $200 \mathrm{ml}$ of sodium hypochlorite per liter of distilled water for ten minutes. Soon after, they were washed again in running and placed in water on a paper towel until they were fully dried. protein structure, fiber, iron, calcium, among others (ROCK, DRC et. al, 2008). By presenting succulent and edible leaves, the ora-pro-nobis can be used in preparations of typical dishes of some regions.

Originating in the Americas (riparian forests of the Cerrado and Atlantic Forest), where native varieties of this vegetable perennial, rustic and resistant to drought in Florida, in the United States and in southeastern Brazil, MAP (MINISTÉRIO DA AGRICULTURA, PECUÁRIA E ABASTECIMENTO, 2010).

The popular name ora-pro-nobis comes from Latin and is due to the fact that, according to legend, the gold cycle times, in the village of San José, where today has Sabara, are São João Del-Rei, Ouro Preto and Tiradentes, European residents priests, taking advantage of the strength of thorns scattered across it, they used the plant as a living fence to encircle the churches (MARTINS, 2010) .

Given the above, this study aims to analyze the bromatological plant, evaluating its nutritional quality, macronutrients and micronutrients as well as perform sensory test the dough made with the plan to verify its acceptability.

Samples were weighed on the first day October 2012, to obtain fresh weight and then sent to a circulating oven and air exchange to a temperature of $60^{\circ} \mathrm{C}$ for 72 hours. When removing samples from the oven, the dry weight thereof was observed, yielding an average of $79.8 \%$ moisture and $20.2 \%$ dry matter.

Then the leaves were already dry ground, turning into flour, this was taking samples were taken for analysis of macronutrients, micronutrients and chemical. To prepare the noodles like pasta dough was used the ingredients: wheat flour without yeast, water, salt, eggs, ora- 
pro-nobis dehydrated in the proportions $0.00 \%, 5 \%, 7.5 \%$ and $10 \%$ (Tabela 1). The ingredients were mixed one at a time in the order just described. Then the dough was extruded and molded noodle like, into strips of $50 \mathrm{~cm}$ by $3 \mathrm{~mm}$ thick, which were stretched over stainless steel grilles and dried in an oven with circulation and air exchange (MA 35 Marconi) forced ventilation with air at a temperature of (25 $\left.{ }^{\circ} \mathrm{C}\right)$ for 12 hours. The spaghetti type noodles were packed in plastic bags and stored at room temperature for further chemical and sensory analysis.

Table 1. Ingredients ( $\mathrm{g} \%$ ) to the formulation of conventional noodles tagliatelle type and with the addition of Pereskia aculeata dehydrated

\begin{tabular}{lccccl}
\hline Formulations & Wheat Flour & \multicolumn{1}{c}{ Eggs } & Water & Salt & Ora-pró-nobis \\
\hline Pasta1 & $500(31.88 \%)$ & $37.5(2.39 \%)$ & $237(15.15 \%)$ & $9(0.57 \%)$ & $0(0.00 \%)$ \\
Pasta2 & $500(31.68 \%)$ & $37.5(2.37 \%)$ & $237(15.05 \%)$ & $9(0.70 \%)$ & $5(0.31 \%)$ \\
Pasta3 & $500(31.68 \%)$ & $37.5(2.37 \%)$ & $237(15.00 \%)$ & $9(0.57 \%)$ & $7(0.47 \%)$ \\
Pasta4 & $500(31.48 \%)$ & $37.5(31.48 \%)$ & $237(29.91 \%)$ & $9(0.56 \%)$ & $10(0.63 \%)$ \\
\hline
\end{tabular}

Each of the masses was used to prepare two portions, one boiled and the other only with garlic and oil prepared according to the figures $2,3,4$ and 5 illustrate the prepared pasta and offered to the public. The four different masses were evaluated for its acceptability with respect to 5 aspects: appearance, color, taste, texture and overall acceptability. We used

\section{RESULTS AND DISCUSSION}

Analyzes were performed of macronutrients, micronutrients and bromatological for the dehydrated leaves, being found the following results: macronutrients: total number (26.5), phosphorus (1.87), potassium (33.8),
21 judges chosen at random. Each proved all portions prepared from 4 mass listed in the table above. Each portion was divided provided of: 1) just cooked and 2) made with oil and garlic. Each of the judges, a sensory analysis grid was delivered to point the preference level of the offered parts, ranging 1-9, one for nine disliked very much to like very much.

Table 2. Plant tissue analysis results ora-pro-nobis

\begin{tabular}{|c|c|c|c|}
\hline \multicolumn{2}{|c|}{ Macronutrientes / $\mathbf{g ~ K g} \mathbf{~}^{-1}$} & \multicolumn{2}{|c|}{ Micronutrientes / $\mathbf{~ g ~ K \mathbf { ~ g } ^ { - 1 }}$} \\
\hline $\mathrm{N}$ total & 26.5 & $\mathrm{Na}$ & - \\
\hline $\mathrm{P}$ & 1.87 & $\mathrm{~B}$ & 54.5 \\
\hline $\mathrm{K}$ & 33.8 & $\mathrm{Cu}$ & 0.7 \\
\hline $\mathrm{Ca}$ & 28.8 & $\mathrm{Fe}$ & 106.1 \\
\hline $\mathrm{Mg}$ & 10.5 & $\mathrm{Mn}$ & 245.2 \\
\hline $\mathrm{S}$ & 1.5 & $\mathrm{Zn}$ & 40.0 \\
\hline
\end{tabular}

The results of the chemical composition of the dried leaves showed a percentage of dry matter $(93 \%)$, ether extract $(5.05 \%)$, mineral material $(16,21)$, calcium (28.8), magnesium (10.5), sulfur (1.5), and the results for the micronutrients were: boron (54.5), copper (0.7), iron (106.1,) manganese (245.2), and zinc (40.0), as shown in Table 2 below. crude fiber (11.94), crude protein (17.63), nitrogen free extract (48.70), total digestible nutrients (72.08) such data are shown in Table 3 below. 
Table 3. Results of the chemical composition.

\begin{tabular}{lllllll}
\hline MS \% & EE \% & M. mineral\% & FB \% & PB \% & ENN \% & *NDT \\
\hline 93.16 & 5.05 & 16.21 & 11.94 & 17.63 & 48.70 & 72.08 \\
\hline
\end{tabular}

The results of the chemical composition as shown ora-pró-nobis noodle dough which were prepared with dry matter and milled in the following percentage sample one $(0 \%)$, Witness two (5\%), Sample 3 (75\%), sample 4 (10\%), shows the percentage of EE (etério extract), M. min. (mineral matter), SD (final drying), FB (crude fiber), CP (crude protein), NFE (nitrogen free extract), TDN (total digestible nutrients through this data can see that the sample 4 to $10 \%$ have a percentage of 20.1715 proteins. the data are shown in Table 4 below.

Sensory analysis shows the average marks awarded by the judges. Such notes could range 1-9, with 1 being very much disliked and 9 liked very much.

Table 4. Results of the chemical analysis of pasta masses.

\begin{tabular}{|c|c|c|c|c|c|c|c|c|}
\hline ASTA & M.MIN. & $\mathrm{EE}$ & $\mathrm{SD} 1055^{\circ} \mathrm{C}$ & $\mathrm{PS} 55^{\circ} \mathrm{C}$ & $\mathrm{FB}$ & PB & ENN & $\%$ NDT \\
\hline 1 & 2.0551 & 1.9148 & 93.276 & - & 0.5135 & 14.562 & 80.955 & 79.707 \\
\hline 2 & 1.8166 & 1.1721 & 92.69 & - & 0.8397 & 15.335 & 80.837 & 78.971 \\
\hline 3 & 1.5205 & 2.0702 & 74.646 & - & 0.9547 & 19.099 & 76.355 & 78.902 \\
\hline 4 & 2.3534 & 1.9782 & 93.02 & - & 0.4263 & 20.172 & 75.071 & 78.388 \\
\hline
\end{tabular}

Is important to highlight, it was also held as sample preparation. The mass was first prepared without ora-pró-nobis i.e. $0 \%$, the mass 2 shows $5 \%$ ora-pró-nobis, the dough 3 is $7.5 \%$ ora-pró-nobis, and finally, the mass 4 shows $10 \%$ ora-pronobis. Table 5 illustrates the mean and variance analysis of data obtained through the notes of the judges.

Table 5. Average ratings of respondents

\begin{tabular}{lllll}
\hline & Pasta1 & Pasta2 & Pasta3 & Pasta4 \\
\hline Appearance & $6.41 \mathrm{~b}$ & $6.14 \mathrm{~b}$ & $6.41 \mathrm{~b}$ & $7.05 \mathrm{a}$ \\
Color & $6.59 \mathrm{a}$ & $6.27 \mathrm{a}$ & $6.64 \mathrm{a}$ & $6.91 \mathrm{a}$ \\
Flavor & $6.95 \mathrm{a}$ & $6.41 \mathrm{a}$ & $6.77 \mathrm{a}$ & $7.09 \mathrm{a}$ \\
Texture & $6.50 \mathrm{~b}$ & $6.45 \mathrm{~b}$ & $6.86 \mathrm{~b}$ & $7.18 \mathrm{a}$ \\
\hline
\end{tabular}

Values followed by the same letter (line), do not differ by Tukey test at $5 \%$ probability.

It is found that there is no significant difference between the masses using analysis of variance, Tukey test $5 \%$.

The results are displayed graphically for easy viewing. Figure 6, illustrated the amount of acceptance of respondents in the mass with $0 \%$ ora-pro-nobis, for each of the variables (appearance, color, taste and texture). It was found that $25 \%$ enjoyed the texture, $24 \%$ enjoyed the look, 26\% enjoyed the taste and $25 \%$ appreciated the color. Figure 6 shows that all variables had virtually the same acceptance of respondents. 


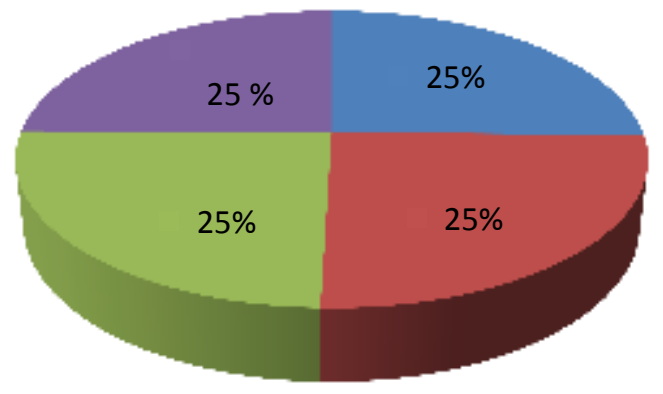

- Appearance

- Color

- Flavor

- Texture

Figure 6. The pasta acceptance 1 ( $0 \%$ of ora-pro-nobis) by respondents.

When comparing the average scores given to the masses $1,2,3$ and 4 , we observe that the appearance of mass $2(5 \%$ ora-pro-nobis) compared to trim mass INSTANCE 4 (10\% ora-pro-nobis), got little difference in acceptability, the texture of the dough 2 (5\% ora-pro-nobis) in comparison with the mass 4 (5\% either ora-pro-nobis) gave little difference. The bor sa mass 2 (5\% ora-pro-nobis) by comparing at Comparisons will with the mass 4 (10\% ora-pro-nobis), it is perceived difference between the two mass acceptability of the judges. To stop the second mass (5\% ora-pro-nobis) with the mass 4 (10\% ora-pro-nobis) also there is difference. Such data can be seen in Figure 7.

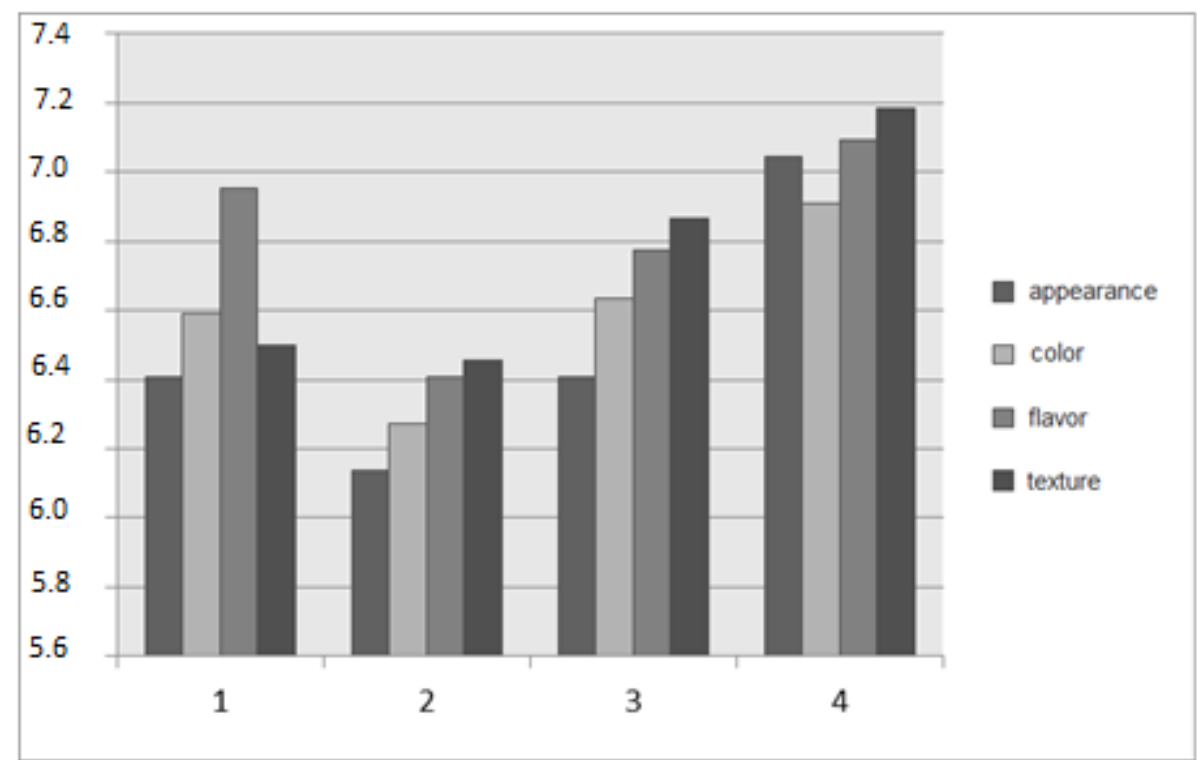

Figure 7. Comparing the assessed variables in the masses $(0 \%, 5 \%, 7.5 \%$ and $10 \%)$ ora-pronobis 


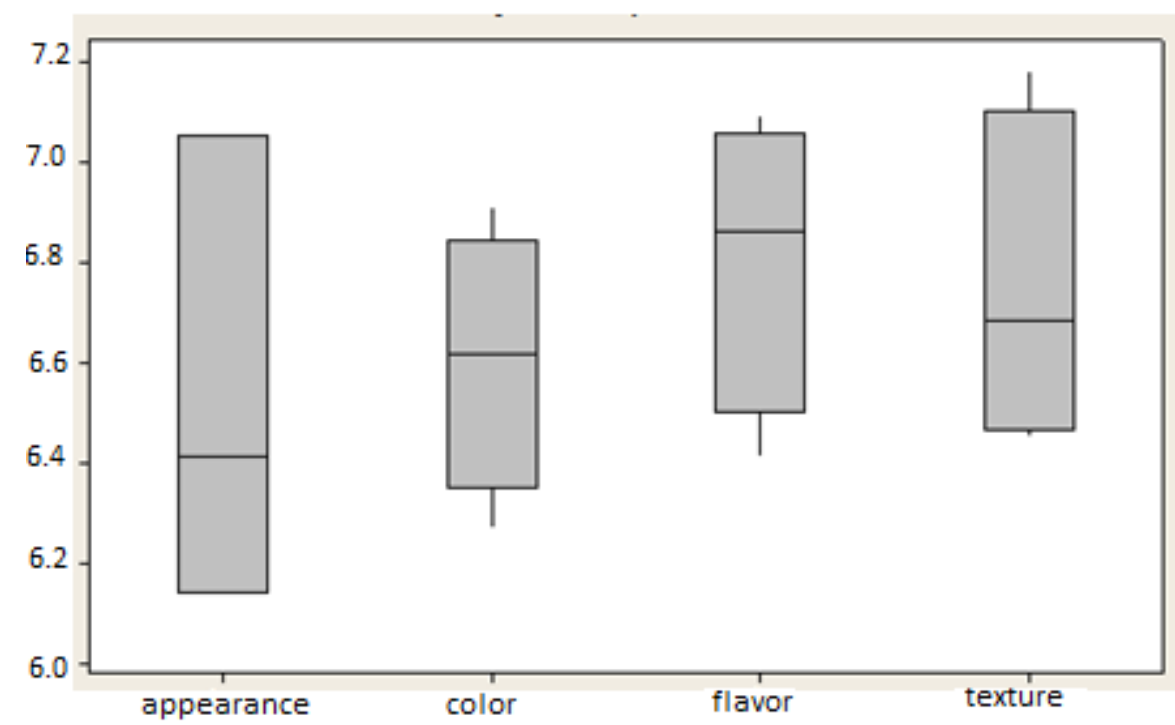

Figure 8. Comparing the assessed variables in the masses $(0 \%, 5 \%, 7.5 \%$ and $10 \%)$ ora-pronobis.

Figure 8 graphically shows the central position of the data (median), and the tendency promotes any indication of symmetry between the data. It can be said that the data keeps the same pattern in the masses confectioned regarding the variables appearance, color, taste and texture. But such differences are not

\section{CONCLUSIONS}

Unconventional vegetables are an alternative for poor people because they are good sources of nutrients presenting easy availability, and low market value. Therefore, this study characterized the chemical and sensory analysis of pasta type noodles with different proportions of ora-pro-nobis $(0 \%, 5 \%, 7.5 \%$ and $10 \%)$.

The chemical analysis showed a high level of potassium (33.8), calcium (28.8), magnesium (10.5), sulfur (1.5) and phosphorus (1.87), which strengthens the possibility of using the vegetables in the fight against hunger and the nutritional deficiencies of the population.

Among the masses analyzed sensorially there were no significant significant at the 5\% level based on analysis of variance carried out with the data obtained in minitab 7.0.

Statistical analysis adopted in this work were established such as in Pereira et al. (2013) and Chacur et al. (2012, 2013, 2014).

differences between the acceptability by the judges, the pasta portion with proportion $10 \%$ ora-pro-nobis (mass 4). Which proves that in addition to rich in iron and protein, the sheet is tasty and well accepted? Also for the descriptive analysis of the data there was great acceptance in the mass 3 ( $7.5 \%$ ora-pro-nobis). The use of vegetable ora-pro-nobis in the preparation of various food products contributes to increased cultivation and to improve the population diet quality.

The authors thank the Faculty of Sciences and Technology of Presidente Prudente, the University of West Paulista (UNOESTE) for their collaboration in carrying out this work. 


\section{REFERENCES}

AZEVEDO M; KRUEL, F. Medicinal and ritual plants. Available at: <http://www CESUMAR br / prppge / research /.../ ariane_giachini_santos_2.pdf..>. Access on: 10 June 2015.

BRAZIL. AJEUM OF BRAZIL. Available at: <http://www.sabara.mg.gov.br>. Access on: 10 June 2015.

BRAZIL. GLOBO RURAL MAGAZINE. Available at: <http://Revistagloborural globo.com>. Access on: 10 June 2015.

BRAZIL. MINISTRY OF AGRICULTURE. Livestock and Supply. Available at: <http://agricultura.gov.br>. Access on: 10 June 2015.

CHACUR, M. G. M.; MARTINS, E. A. F.; SILVA, A. A.; GUABERTO, L. M.; GABRIEL FILHO, L.R.A.; SANCHES, O. C.; OBA, E. Morfometria corpórea, características do sêmen, proteínas seminais e testosterona em cervos Cervus unicolor, em cativeiro. Arquivo Brasileiro de Medicina Veterinária e Zootecnia. v.66, p.1392-1400, 2014.

CHACUR, M. G. M.; MIZUSAKI, K. T.; GABRIEL FILHO, L. R. A.; OBA, E.; RAMOS, A. A. Seasonal Effects on Semen and Testosterone in Zebu and Taurine Bulls. Acta Scientiae Veterinariae. v.41, 2013.

CHACUR, M. G. M.; MIZUSAKI, K. T.; SANTOS, F. H.; CESARE, A. G.; GABRIEL FILHO, L. R. A.; OBA, E.; RAMOS, A. A. Influência da estação do ano nas características do sêmen e na concentração de hormônios em touros Nelore e Simental. Arquivo Brasileiro de Medicina Veterinária e Zootecnia. v.64, p.540-546, 2012.

EMBRAPA vegetables, available at: <http:. //www.cnph Embrapa .uk / index. php <Http://www.melissotroficas.com.br>. Access on: 10 June 2015.
EMBRAPA, National Center for Horticultural Research, bertalha. Available at:

$<$ http://www.cnph.embrapa.br/bib/saibaqu e/ bertalha.htm>. Access on: 10 June 2015.

PEREIRA, D. F.; BATISTA, E. S.; SANCHES, F. T.; GABRIEL FILHO, LUÍS ROBERTO ALMEIDA; BUENO, L. G. F. Comportamento de poedeiras criadas a diferentes densidades e tamanhos de grupo em ambiente enriquecido. Pesquisa Agropecuária Brasileira. v.48, p.682-688, 2013.

ROCK, D.R.C. et. al. Macaroni added orapro -nóbis (Pereskia aculeata Miller) dehydrated. Alim. Nutr., Araraquara. v.19, n.4, p.459-465, 2008. 